ISSN 0258-7122 (Print), 2408-8293 (Online)

Bangladesh J. Agril. Res. 41(4): 695-711, December 2016

\title{
OPPORTUNITIES OF GROUNDNUT CULTIVATION AND MARKETING SYSTEM IN CHAR LANDS OF BANGLADESH
}

\author{
M. S. HOQ ${ }^{1}$, Q. M. S. ISLAM ${ }^{2}$, S. KHANDOKER ${ }^{3}$ AND M. A. MATIN ${ }^{4}$
}

\begin{abstract}
Bangladesh has vast char area but most of the char lands are not suitable for crop production. So the present study was undertaken to examine the suitability of crop production by assessing adoption, relative profitability, marketing system, production and marketing problems of rabi season groundnut in char lands of Faridpur, Jamalpur, and Kishoreganj districts during 2013-2014. The sample size of the study was 225 including 90 groundnut farmers and 135 traders. The study revealed that the highest $(56 \%)$ percent of groundnut farmers cultivated Dhaka-1 variety and only $23 \%$ of all farmers cultivated BARI chinabadam-8.The per hectare production cost of groundnut was Tk 61,547, net return was Tk.42,033 and BCR was 1.68. The partial budgeting analysis showed that if the farmers cultivated groundnut instead of its competitive crops, they would receive Tk. 24,445 additional to sesame and Tk.21,990 additional to wheat cultivation. The average estimated marketing costs was highest (Tk.1388/quintal) for Stockist and lowest (Tk.55/quintal) for Arathdar. Net marketing margin was also highest (Tk.1212/quintal) for Stockist and lowest (Tk.59/quintal) for Arathdar. Marketing chain-v was the most efficient than other five chains because it has single involvement of intermediary. The major problems identified by farmers were lack of irrigation facilities (34\%), low rate of seed germination (31\%), and lack of cultivable land (29\%). Major marketing problems were lack of cash capital (82\%), and lack of storage facilities $(55 \%)$ etc. Arrangement of institutional credit with low interest rate $(80 \%)$, collateral free credit $(45 \%)$, and arrangement of storage facilities $(72 \%)$ were the trader's opinion to minimize the marketing problems of groundnut. Therefore the study will be helpful to increase groundnut cultivation and improved the marketing system in char lands of Bangladesh.
\end{abstract}

Keywords: Adoption, relative profitability, marketing efficiency, groundnut and char lands

\section{Introduction}

Bangladesh has vast Char land in different districts embraced by Padma, Meghna, Jamuna, Brahmaputra and other rivers which has highly potential for groundnut production. In 1993 the estimated total area covered by chars in

${ }^{1}$ Scientific Officer, Agricultural Economics Division, Bangladesh Agricultural Research Institute (BARI), Joydebpur, Gazipur, ${ }^{2}$ Principal Scientific Officer, Agricultural Economics Division, BARI, Joydebpur, Gazipur, ${ }^{3}$ Scientific officer, Agricultural Economics Division, BARI, Joydebpur, Gazipur, ${ }^{4}$ Chief Scientific Officer, Agricultural Economics Division, BARI, Joydebpur,Gazipur, Bangladesh. 
Bangladesh was 1,722 square kilometres. During the period of 1989 to 1993 , char areas increased in all rivers, except in the upper Meghna. The net increase in char area during this period amounted to 36,000 ha which is equivalent to about 25\% of total char area during 1984 (Rahman and Davis, 2005).This trend is increasing day by day. The cropping intensity of char land is increasing day by day. Now a days several crops such as maize, wheat, sesame, potato, groundnut etc. were produced in different parts of char lands in Bangladesh. It's substantially changed the socioeconomic life of the char lands people. The total groundnut production was 0.75 lac MT from 0.30 lac hectares of cultivated land in Bangladesh (BBS, 2011). The overall groundnut production might be around 0.32 lac tones from 0.20 lac hectares of cultivated char land area during both Rabi and Kharif seasons (BSS, 2012). Because of lower farming cost and excellent market price with huge demand, char farmers have been expanding groundnut cultivation every year in the char lands.

Few years back the char people mostly affected by river erosion had to rush to towns for earnings either as day labor or rickshaws and vans puller. Now they found a hope of survival by growing groundnut without much investment and hassle. Another advantage of groundnut cultivation is that no natural calamities except flood can damage this crop. The farmer said it does not require any fertilizer, irrigation or pesticide for growing the crop (BSS, 2013).On the other hand groundnut cultivation has no adverse impact on environment rather its green plants help maintained ecological balance in the area.The increased production of groundnut greatly depends on its efficient marketing system. Different constraints from production to consumer's level were emerged including transportation, price fluctuation, buyer etc., which may caused hamper in decision-making of the farmers to cultivate groundnut. Therefore, the study would give us an efficient marketing system of groundnut. Recognizing the above importance and suitability of groundnut production and marketing in char lands the study was undertaken with the following objectives.

\section{Objectives of the study}

1. To determine the adoption level, relative profitability and opportunities of groundnut cultivation in char lands;

2. To examine the existing marketing system of groundnut in char lands;

3. To estimate the marketing cost, margin and marketing efficiency at different levels;

4. To identify the major production and marketing problems of groundnut;

5. To derive some policy recommendation from the study. 


\section{Materials and Method}

Study area: Three districts Faridpur, Jamalpur and Kisoreganj were selected for the rabi groundnut production and marketing survey. Two upazilas from each district were selected on the basis of where char lands are available for the rabi groundnut production. Markets were selected where the maximum product were marketed from the production area.

Methods of data collection: A multi-stage simple random sampling technique was followed for the selection of district, upazila, block and market for the collection of data. The populations of block and market were grouped into different strata like; Farmer, Faria, Bepari etc. and the simple random sampling technique was used for drawing the desired sample from each strata. The study was conducted during the period in 2013-14. Data were collected from both primary and secondary sources.

Sampling procedure and size: A total of 225 sample taking 75 from each area were interviewed for the present study. Among the 75 samples, 30 farmers and 45 traders were selected from each district. The sample distribution of each district was 30 farmers and 45 traders $(10$ Faria +8 Bepari +5 Arathdar +8 Paiker +10 Retailer +4 Stockist). In selecting the types of traders a list of intermediaries were prepared with the help of different types of intermediaries or market authorities existing in the market. Then the required amounts of traders were proportionally selected from the list.

\section{Analytical techniques}

\section{Cost and return analysis}

Following profit equation were used to assess the profitability of groundnut cultivation. Net return from crop cultivation was:

$$
\pi_{\mathrm{ijk}}=\mathrm{P}_{\mathrm{ijk} .} \mathrm{Q}_{\mathrm{ijk}}-\left(\mathrm{TVC}_{\mathrm{ijk}}+\mathrm{TFC}_{\mathrm{ijk}}\right)
$$

Where, $\pi=$ Per hectare net return from ith crops

$\mathrm{P}_{\mathrm{ijk}}=$ Per unit price of ith crops $(\mathrm{Tk} / \mathrm{kg})$

$\mathrm{Q}_{\mathrm{ijk}}=$ Quantity of ith crops $(\mathrm{Kg} / \mathrm{ha})$

$\mathrm{TVC}_{\mathrm{ijk}}=$ Total variable cost of ith crops $(\mathrm{Tk} / \mathrm{ha})$

$\mathrm{TFC}_{\mathrm{ijk}}=$ Total fixed cost of ith crops $(\mathrm{Tk} / \mathrm{ha})$

$\mathrm{i}(1 . .4)=$ number of crops,

$\mathrm{j}(1 . .3)=$ number of location,

$\mathrm{k}(1 . .90)=$ number of farmers 
Partial budgeting techniques were used for analysis of relative economic performance of Groundnut with its competitive crops.

\section{Marketing margin analysis}

Marketing margin of the traders were calculated by using the following formula

$$
\mathrm{GM}_{\mathrm{ij}}=\mathrm{PR}_{\mathrm{ij}}-\mathrm{PP}_{\mathrm{ij}}
$$

Where,

$\mathrm{GM}_{\mathrm{ij}}=$ Gross margin (Tk/quintal) for ith intermediary of jth crops

$\mathrm{PR}_{\mathrm{ij}}=$ Price Received (Tk/quintal) for ith intermediary of jth crops

$\mathrm{PP}_{\mathrm{ij}}=$ Price paid (Tk/quintal) by ith intermediary of $\mathrm{jth}$ crops

$$
\mathrm{NM}_{\mathrm{ij}}=\mathrm{GM}_{\mathrm{ij}}-\mathrm{Mc}_{\mathrm{ij}}
$$

Where,

$\mathrm{NM}_{\mathrm{ij}}=\mathrm{Net}$ margin $(\mathrm{Tk} /$ quintal) for ith intermediary of jth crops

$\mathrm{MC}_{\mathrm{ij}}=$ Marketing cost incurred (Tk/ quintal) by ith intermediary of jth crops

\section{Marketing efficiency}

Acharya's method was used for estimating marketing efficiency (Acharya and Agarwal, 2004) in the present study.

$$
\mathrm{ME}=\frac{\mathrm{FP}}{\mathrm{MC}+\mathbf{M M}}
$$

Where,

$$
\begin{aligned}
& \mathrm{ME}=\text { Marketing efficiency } . \\
& \mathrm{FP}=\text { Net price received by farmers } \\
& \mathrm{MC}=\text { Total marketing cost } \\
& \mathrm{MM}=\text { Total net marketing margin of intermediaries. }
\end{aligned}
$$

A higher value of ME denotes higher level of efficiency and vice versa. Descriptive statistics and tabular analysis were also used for the analysis of data.

\section{Results and Discussion}

The study goes through the two parts, such as groundnut production and groundnut marketing system aiming to fulfill the objectives of the study. The results regarding production and marketing of groundnut are presented and discussed below specifically. 


\section{Adoption of groundnut variety}

Both HYV and local variety were being cultivated in the study areas except Faridpur. In Faridpur 93\% farmers cultivated Dhaka-1 variety and remaining 7\% farmer used local variety. In case of Kishoreganj $7 \%$ farmer cultivated BARI chinabadam-9, 67\% farmers used Dhaka- 1 and the rest $27 \%$ farmers used local variety. On the other hand, in Jamalpur $70 \%$ farmers cultivated BARI Chinabadam- $8,13 \%$ farmers used BARI Chinabadam-9, $10 \%$ famers used BINA Chinabadam-4 and 7\% farmers cultivated Dhaka-1 variety. Adoption rate of HYV seed in Jamalpur was high because HYV seed of groundnut were supplied by the project of ICRISAT (Table 1).

Table 1. Percent of farmer's adopted of groundnut variety

\begin{tabular}{l|c|c|c|c}
\hline \multicolumn{1}{c|}{ Variety name } & $\begin{array}{c}\text { Faridpur } \\
(\mathrm{n}=30)\end{array}$ & $\begin{array}{c}\text { Jamalpur } \\
(\mathrm{n}=30)\end{array}$ & $\begin{array}{c}\text { Kishoreganj } \\
(\mathrm{n}=30)\end{array}$ & $\begin{array}{c}\text { All area } \\
(\mathrm{n}=90)\end{array}$ \\
\hline BARI chinabadam-8 & - & 70 & - & 23 \\
BARI chinabadam-9 & - & 13 & 7 & 7 \\
BINA chinabadam-4 & - & 10 & - & 3 \\
Dhaka-1 & 93 & 7 & 67 & 56 \\
Local & 7 & - & 27 & 11 \\
Total & 100 & 100 & 100 & 100 \\
\hline
\end{tabular}

Table 2. Per hectare input use pattern of groundnut cultivation

\begin{tabular}{lccccc}
\hline \multicolumn{1}{c|}{ Particulars } & Faridpur & Jamalpur & Kishoreganj & All Area \\
\hline Human Labour (Man-days/ha) & 101 & 119 & 106 & 108 \\
Own Labour (Man-days/ha) & 56 & 73 & 63 & 64 \\
$\quad$ Hired Labour (Man-days/ha) & 45 & 45 & 43 & 44 \\
Seed (Kg/ha) & 106 & 120 & 116 & 114 \\
Fertilizer & & & & \\
$\quad$ Urea (Kg/ha) & 12 & 41 & 10 & 21 \\
TSP (Kg/ha) & 5 & 34 & 3 & 14 \\
MoP (Kg/ha) & 4 & 37 & 8 & 16 \\
DAP (Kg/ha) & 0 & 61 & 0 & 20 \\
Gypsum (Kg/ha) & 0 & 14 & 0 & 5 \\
\hline
\end{tabular}

\section{Input use pattern}

On an average, 108 man-days of human labour per hectare were used for groundnut cultivation but it was vary area to area. The highest number of human labour was used in Jamalpur (119 man-days/ha) and lowest in Faridpur (101 man-days/ha). Farmers used $114 \mathrm{~kg}$ groundnut as a seed per hectare in all area. Highest seed rate was used in Jamalpur (120 kg/ha) and lowest in Faridpur (106 $\mathrm{Kg} / \mathrm{ha}$ ) for groundnut cultivation. The respondent farmers applied urea, TSP, 
MoP, DAP and gypsum at the rate of $21 \mathrm{~kg} / \mathrm{ha}, 14 \mathrm{~kg} / \mathrm{ha}$ and $16 \mathrm{~kg} / \mathrm{ha}, 20 \mathrm{~kg} / \mathrm{ha}$ and $5 \mathrm{~kg} / \mathrm{ha}$, respectively. The highest amount of fertilizers were used by the farmers of Jamalpur because ICRISAT project supplied fertilizers. On the other hand, the farmers of Kishoreganj and Faridpur were used very less amount of fertilizer and maximum farmers were not using any fertilizer in their field (Table 2).

\section{Cost of production}

All variable costs like human labour, land preparation, seed, manure, fertilizers, insecticides, irrigation and interest on operating capital were considered for calculating per hectare cost of groundnut cultivation. Only land use cost was considered as a fixed cost for groundnut cultivation. The land use cost was calculated on the basis of lease value of land. Finally total cost was determined by adding fixed cost and variable cost. On an average, total cost of groundnut production was Tk.61,547/ha in which total variable cost was Tk.51,526/ha and fixed cost was Tk.10,021/ha. Highest cost was found in Jamalpur district (Tk.66,570/ha) and lowest cost was found in Faridpur district(Tk.56,895/ha).Because farmers of Jamalpur applied fertilizer, irrigation water and pesticide adequately. On the other hand the farmers of Faridpur and Kishoreganj applied less amount of fertilizer, irrigation water and pesticide (Table 3).

Table 3. Cost of groundnut production in the study areas (Tk/ha)

\begin{tabular}{lccccc}
\hline \multicolumn{1}{c|}{ Particulars } & Faridpur & Jamalpur & Kishoreganj & All area \\
\hline A.Total variable Cost & 47539 & 56153 & 50884 & 51526 \\
Land preparation & 7169 & 5798 & 6905 & 6624 \\
Human labour & 29005 & 33185 & 29695 & 30628 \\
$\quad$ Family labour & 16187 & 20646 & 17701 & 18178 \\
$\quad$ Hired labour & 12818 & 12538 & 11994 & 12450 \\
Seed & 9185 & 8519 & 11436 & 9713 \\
Fertilizer & 441 & 4011 & 426 & 1626 \\
$\quad$ Urea & 225 & 811 & 208 & 415 \\
$\quad$ TSP & 154 & 891 & 88 & 378 \\
$\quad$ MP & 62 & 603 & 130 & 265 \\
$\quad$ DAP & 0 & 1817 & 0 & 606 \\
$\quad$ Gypsum & 0 & 138 & 0 & 46 \\
Irrigation & 1014 & 3516 & 1643 & 2058 \\
Insecticide/Pesticide & 23 & 51 & 27 & 34 \\
Interest on operating capital & 702 & 826 & 752 & 760 \\
B.Total fixed Cost & 9356 & 10416 & 10292 & 10021 \\
Land use cost & 9356 & 10416 & 10292 & 10021 \\
Total cost/ Full cost (A+B) & 56895 & 66570 & 61176 & 61547 \\
\hline
\end{tabular}




\section{Return}

Average yield of groundnut was found at $2087 \mathrm{~kg} / \mathrm{ha}$. The highest yield was found in Jamalpur $(2260 \mathrm{~kg} / \mathrm{ha})$ and the lowest in Faridpur $(1920 \mathrm{~kg} / \mathrm{ha})$. The average gross return, gross margin and net return were Tk.103580, Tk.52054 and Tk.42033 per hectare respectively. The BCR of groundnut production was 1.68 in all area (Table 4).

Table 4. Yield, gross return, net return of groundnut in the study areas

\begin{tabular}{l|ccc|c}
\hline \multicolumn{1}{c}{ Particulars } & Faridpur & Jamalpur & Kishoreganj & All Aera \\
\hline Average of yield(Kg/ha) & 1920 & 2260 & 2080 & 2087 \\
Average of sale price(Tk/kg) & 50 & 49 & 50 & 50 \\
Gross return(Tk/ha) & 96000 & 110740 & 104000 & 103580 \\
Total variable cost(Tk/ha) & 47539 & 56153 & 50884 & 51526 \\
Gross margin(Tk/ha) & 48461 & 54587 & 53116 & 52054 \\
Total cost(Tk/ha) & 56895 & 66570 & 61176 & 61547 \\
Net return(Tk/ha) & 39105 & 44170 & 42824 & 42033 \\
BCR on full cost basis & 1.69 & 1.66 & 1.70 & 1.68 \\
\hline
\end{tabular}

\section{Relative profitability of groundnut cultivation}

The groundnut farmers cultivated different competitive crops (Table 5). Based on the highest number of cultivating farmers, sesame from Faridpur district, wheat from Jamalpur district and potato from Kishoreganj district were selected as competitive crops. A competitive economic performance of groundnut was evaluated through comparing with those selected crops.

Table 5. Distribution of farmers cultivated competitive crops in the study areas

\begin{tabular}{l|c|c|c|c}
\hline Competitive Crops & Faridpur & Jamalpur & Kishoreganj & All area \\
\hline Aman & 3 & - & - & 3 \\
Chili & - & 2 & 4 & 6 \\
Lentil & - & 6 & - & 6 \\
Mungbean & 1 & & - & 1 \\
Mustard & - & 3 & - & 3 \\
Onion & - & 4 & - & 4 \\
Potato & - & 1 & 19 & 20 \\
Sweet potato & - & - & 4 & 4 \\
Sesame & 10 & - & - & 10 \\
Wheat & 5 & 8 & 1 & 14 \\
Wheat+Lentil & - & 2 & - & 2 \\
Wheat+Mustard & - & 1 & - & 1 \\
None & 11 & 3 & 2 & 16 \\
Total & 30 & 30 & 30 & 90 \\
\hline
\end{tabular}




\section{Relative profitability of groundnut with selected competitive crops}

The total cost of groundnut production and its competitive crops like sesame, wheat and potato were Tk.61, 547 and Tk.31,990, Tk.49,269 and 1,27,396 per hectare respectively. The net returns of the above crops were Tk.42,033, Tk.14,650, Tk.22,491 and Tk.70,205 per hectare respectively. Net return of groundnut is higher than its competitive crop sesame and wheat and lower than potato. But Benefit-Cost ratio (BCR) of groundnut (1.68) is higher than sesame (1.46), wheat (1.46) and potato (1.55). So groundnut cultivation is more profitable than its competitive crops sesame, wheat and potato (Table 6).

Table 6. Relative profitability of groundnut with its competitive crops

\begin{tabular}{lccccc}
\hline Particulars & Groundnut & Sesame & Wheat & Potato \\
\hline Average of yield(Kg) & 2087 & 1166 & 3120 & 19760 \\
Average of sale price(Tk/kg) & 50 & 40 & 23 & 10 \\
Gross return(Tk/ha) & 103580 & 46640 & 71760 & 197600 \\
Total variable cost(Tk/ha) & 51526 & 24581 & 41860 & 119986 \\
Gross margin(Tk/ha) & 52054 & 21819 & 29900 & 77614 \\
Total cost(Tk/ha) & 61547 & 31990 & 49269 & 127396 \\
Net return(Tk/ha) & 42033 & 14650 & 22491 & 70205 \\
BCR on full cost basis & 1.68 & 1.46 & 1.46 & 1.55 \\
\hline
\end{tabular}

\section{Relative economic performance by using partial budgeting technique}

A partial budget could be prepared to ascertain the effect on the benefit of substituting one enterprise for another without any choice in the enterprise farmland area. In substituting one hectare of groundnut instead of sesame the net changes of benefit was Tk.24,455/ha which was more profitable than sesame. Partial budgeting of groundnut with its competitive crop wheat in Jamalpur indicated that if the farmers cultivated groundnut instead of wheat they received benefit Tk.21,990 per hectare. On the other hand partial budgeting of groundnut with potato indicated that the net changes of profit were negative which reflect that ground cultivation in Kishoreganj is not profitable (Table 7, 8, 9).

Table 7. Partial budgeting of groundnut cultivation with sesame (Tk/ha)

\begin{tabular}{|c|c|c|c|}
\hline Additional costs & BDT & Additional revenue & BDT \\
\hline $\begin{array}{l}\text { Extra cost incurred for producing } \\
\text { groundnut }\end{array}$ & 56,895 & $\begin{array}{l}\text { Extra income earned for } \\
\text { producing groundnut }\end{array}$ & 96,000 \\
\hline $\begin{array}{l}\text { A. Total Additional costs } \\
\text { Reduced Revenue }\end{array}$ & 56,895 & C. Total Additional revenue & 96,000 \\
\hline ved for not & 46,640 & $\begin{array}{l}\text { Reduced Costs } \\
\text { Cost saved for not producing } \\
\text { sesame }\end{array}$ & 31,990 \\
\hline B. Total Reduced Revenue & 46,640 & D. Total Reduced Costs & 31,990 \\
\hline $\begin{array}{l}\text { E. Total Additional costs and } \\
\text { reduced revenue }(A+B)\end{array}$ & $1,03,535$ & $\begin{array}{l}\text { F. Total Additional revenue and } \\
\text { reduced } \operatorname{cost}(C+D)\end{array}$ & $1,27,990$ \\
\hline
\end{tabular}


Table 8. Partial budgeting of groundnut cultivation with wheat (Tk/ha)

\begin{tabular}{|c|c|c|c|}
\hline Additional costs & BDT & Additional revenue & BDT \\
\hline $\begin{array}{l}\text { Extra cost incurred for producing } \\
\text { groundnut }\end{array}$ & 66,259 & $\begin{array}{l}\text { Extra income earned for } \\
\text { producing groundnut }\end{array}$ & $1,10,740$ \\
\hline A. Total Additional cost & 66,259 & C. Total Additional revenue & $1,10,740$ \\
\hline Reduced Revenue & & Reduced Cost & \\
\hline $\begin{array}{l}\text { Income not received for not } \\
\text { producing wheat }\end{array}$ & 71,760 & $\begin{array}{l}\text { Cost saved for not producing } \\
\text { wheat }\end{array}$ & 49,269 \\
\hline B.Total Reduced Revenue & 71,760 & D. Total Reduced Costs & 49,269 \\
\hline $\begin{array}{l}\text { E.Total Additional costs and } \\
\text { reduced revenue }(A+B)\end{array}$ & $1,38,019$ & $\begin{array}{l}\text { F. Total Additional revenue and } \\
\text { reduced } \cos (\mathrm{C}+\mathrm{D})\end{array}$ & $1,60,009$ \\
\hline
\end{tabular}

Net change in profit(F-E) $\quad 21,990$

Table 9. Partial budgeting of groundnut cultivation with potato (Tk/ha)

\begin{tabular}{|c|c|c|c|}
\hline Additional costs & BDT & Additional revenue & BDT \\
\hline $\begin{array}{l}\text { Extra cost incurred for producing } \\
\text { groundnut }\end{array}$ & 61,176 & $\begin{array}{l}\text { Extra income earned } \\
\text { producing groundnut }\end{array}$ & $1,04,000$ \\
\hline A. Total Additional costs & 61,176 & C. Total Additional revenue & $1,04,000$ \\
\hline Reduced Revenue & & Reduced Costs & \\
\hline $\begin{array}{l}\text { Income not received for not } \\
\text { producing potato }\end{array}$ & $1,97,600$ & $\begin{array}{l}\text { Cost saved for not producing } \\
\text { potato }\end{array}$ & $1,27,396$ \\
\hline B. Total Reduced Revenue & $1,97,600$ & D. Total Reduced Costs & $1,27,396$ \\
\hline $\begin{array}{l}\text { E. Total Additional costs and } \\
\text { reduced revenue }(A+B)\end{array}$ & $2,58,776$ & $\begin{array}{l}\text { F. Total Additional revenue and } \\
\text { reduced } \cos (C+D)\end{array}$ & $2,31,396$ \\
\hline
\end{tabular}

Net change in profit(F-E) $\quad-\mathbf{2 7 3 8 0}$

\section{Opportunities of groundnut cultivation in char lands}

There are several opportunities for groundnut cultivation in char lands of Bangladesh. Sixty percent farmers mentioned that sandy soil is appropriate for groundnut production. Others opportunities were less irrigation and fertilizer requirement (54\%), high profit due to low cost of cultivation (51\%), cultivation without irrigation (47\%), High yield compared to input uses (43\%), Low labour requirement (44\%) etc. reported by the farmers(Table 10). Groundnut is a crop that can survive in less or no irrigation in char lands where irrigation facilities is unavailable. 
Table10. Farmer's (\%) responses on opportunities of groundnut cultivation in char lands

\begin{tabular}{lc|c|c|c}
\hline \multicolumn{1}{c|}{$\begin{array}{c}\text { Opportunities of groundnut } \\
\text { cultivation }\end{array}$} & $\begin{array}{c}\text { Faridpur } \\
(\mathrm{n}=30)\end{array}$ & $\begin{array}{c}\text { Jamalpur } \\
(\mathrm{n}=30)\end{array}$ & $\begin{array}{c}\text { Kishoreganj } \\
(\mathrm{n}=30)\end{array}$ & $\begin{array}{c}\text { All area } \\
(\mathrm{n}=90)\end{array}$ \\
\hline $\begin{array}{l}\text { Sandy Soil only appropriate for } \\
\text { groundnut production }\end{array}$ & 67 & 53 & 60 & 60 \\
$\begin{array}{l}\text { Less irrigation and fertilizer required } \\
\text { compared to other crops }\end{array}$ & 63 & 40 & 60 & 54 \\
$\begin{array}{l}\text { High profit due to low cost of } \\
\text { cultivation }\end{array}$ & 63 & 43 & 47 & 51 \\
Cultivation without irrigation & 53 & 27 & 60 & 47 \\
High yield compared to input uses & 50 & 43 & 37 & 43 \\
Low labour requirement & 43 & 50 & 40 & 44 \\
Cash will get at a time & 27 & 40 & 30 & 32 \\
\hline
\end{tabular}

\section{Problems of groundnut cultivation in char lands}

There are several problems of groundnut cultivation in char lands pointed out by the farmers. Lack of irrigation facilities (34\%), Low rate of seed germination (31\%), Lack of cultivable land (29\%), High value of seed (24\%), Lack of cash money $(21 \%)$ and Non-profit tenure system $(22 \%)$ etc. were the major problems of groundnut production in char lands (Table11).

Table 11. Problems of groundnut cultivation responded by the farmers $(\%)$

\begin{tabular}{l|c|c|c|c}
\hline Type of problems & $\begin{array}{c}\text { Faridpur } \\
(\mathrm{n}=30)\end{array}$ & $\begin{array}{c}\text { Jamalpur } \\
(\mathrm{n}=30)\end{array}$ & $\begin{array}{c}\text { Kishoreganj } \\
(\mathrm{n}=30)\end{array}$ & $\begin{array}{c}\text { All area } \\
(\mathrm{n}=90)\end{array}$ \\
\hline Lack of irrigation facilities & 40 & 37 & 27 & 34 \\
Low rate of seed germination & 30 & 37 & 27 & 31 \\
Lack of cultivable land & 33 & 30 & 23 & 29 \\
High value of seed & 27 & 20 & 27 & 24 \\
Incident of flood & 23 & 30 & 20 & 24 \\
Lack of cash money & 23 & 10 & 30 & 21 \\
Non- profit tenure system & 17 & 23 & 27 & 22 \\
Birds destroy field groundnut & 17 & 13 & 13 & 14 \\
High price of fertilizer & 13 & 20 & 17 & 17 \\
Lack of training & 7 & 17 & 10 & 11 \\
Insect \& pest attract & 7 & 23 & 10 & 13 \\
\hline
\end{tabular}




\section{Probable solutions to remove the problems}

Farmers also mentioned some remedial measures to remove the above problems which were listed below. Farmers suggested that, availability of HYV seed $(41 \%)$, interest free agricultural credit (18\%), arrangement of irrigation facilities $(23 \%)$, government assistance in flood protection (19\%) and arrangement of training (14\%) and government incentives to supply inputs in proper time (21\%) will be helpful to remove the problems of groundnut cultivation (Table12).

Table 12. Percent of farmer's responses on probable solutions

\begin{tabular}{l|c|c|c|c}
\hline \multicolumn{1}{c|}{ Probable Solutions } & $\begin{array}{c}\text { Faridpur } \\
(\mathrm{n}=30)\end{array}$ & $\begin{array}{c}\text { Jamalpur } \\
(\mathrm{n}=30)\end{array}$ & $\begin{array}{c}\text { Kishoreganj } \\
(\mathrm{n}=30)\end{array}$ & $\begin{array}{c}\text { All area } \\
(\mathrm{n}=90)\end{array}$ \\
\hline Availability of HYV Seed & 40 & 47 & 37 & 41 \\
$\begin{array}{l}\text { Interest free agricultural credit } \\
\text { Arrangement of irrigation facilities }\end{array}$ & 17 & 17 & 20 & 18 \\
$\begin{array}{l}\text { Government assistance in flood } \\
\text { protection }\end{array}$ & 17 & 13 & 27 & 23 \\
$\begin{array}{l}\text { Arrangement of training } \\
\text { Government incentives to supply } \\
\text { inputs }\end{array}$ & 13 & 20 & 10 & 19 \\
\hline
\end{tabular}

\section{Groundnut marketing system}

\section{Marketing chain}

Marketing chain is the alternative root of products flow from producers to consumers (Khols and Uhl, 1980). Market chain analysis aims to provide information on profitability for the various agents along the market chain (Ferris et al., 2001).

The following major marketing chain was found in the study areas:

Chain-i: Farmer $>$ Faria $>$ Arathdar $>$ Paiker $>$ Retailer $>$ Consumer

Chain-ii: Farmer $>$ Faria $>$ Stockist $>$ Bepari $>$ Retailer $>$ Consumer

Chain-iii: Farmer $>$ Bepari $>$ Arathdar $>$ Paiker $>$ Retailer $>$ Consumer

Chain-iv: Farmer $>$ Paiker $>$ Retailer $>$ Consumer

Chain-v: Farmer $>$ Retailer $>$ Consumer

\section{Characteristics of actors involved in the groundnut marketing chain}

Faria: Faria is a petty trader or small scale business that purchases groundnut from the producer in the village or in the local market and offer the same to the arathdar or bepari. Sometimes he sells his produce directly to the rural retailer or consumers. 
Bepari: Bepari is a professional wholesale traders who make his purchase from producer or faria at the local market, bring their consignment to the urban wholesale market and sell them to the paikar and retailer through arathdar (commission agent).

Arathdar: Arathdar is a commission agent who has a fixed establishment and operates between bepari and retailers, or between farmer and paiker, or between bepari and paiker, or between faria and bepari. They take commission from both of the parties but generally they do not follow any standard rule to take commission.

Paiker: Wholesaler in consuming area is known as paiker, who purchase from bepari through arathdar and sell those to the retailer or consumer.

Retailer: The retailer, the last link in the marketing channel, buys groundnut from arathdar or wholesaler/paiker and sells these to the consumer.

Stockist: Stockist are working in the producing area who purchase wet groundnut from the farmers or faria and dry it in their chatal and store for some period for higher prices.

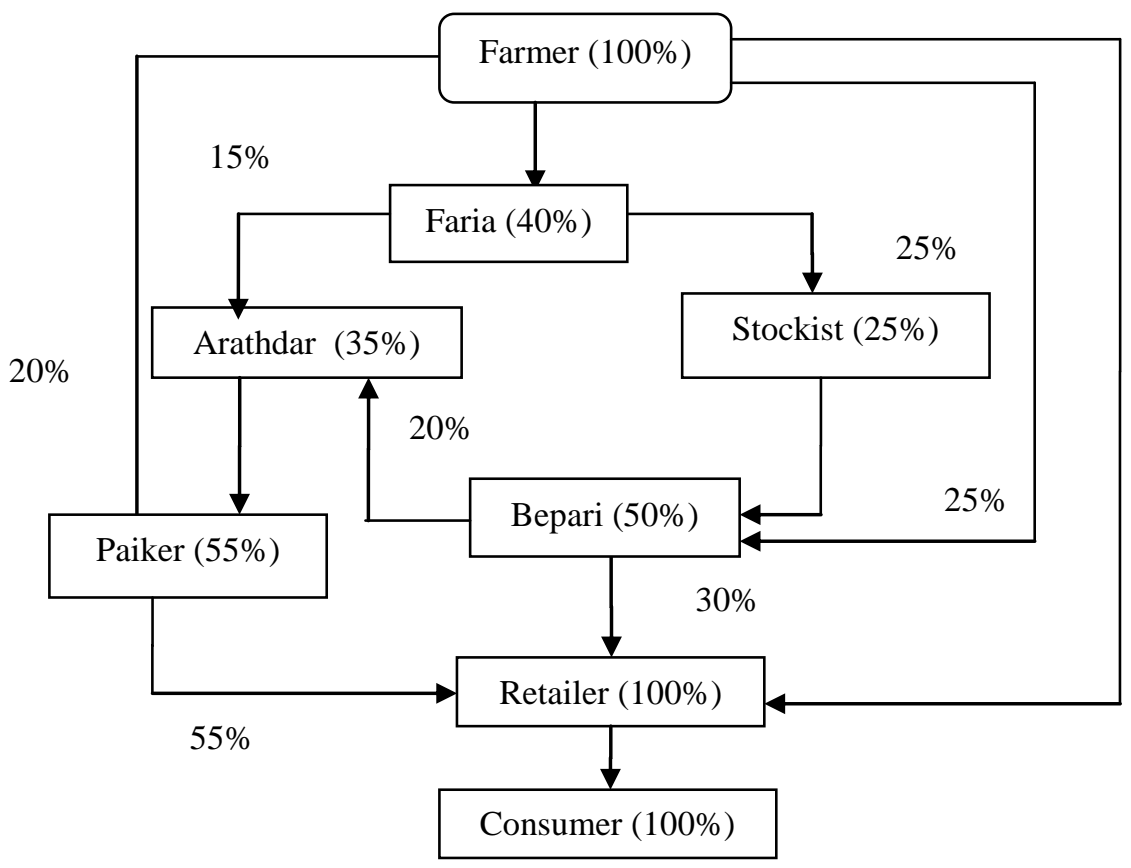

$15 \%$

Fig. 1. Marketing chain of groundnut in the study areas.

\section{Marketing cost of different actors involved in groundnut marketing}

The cost of marketing represents the cost of performing the various marketing functions and operations by various agencies involved in the marketing process 
(Kohls and Uhl, 2005). In other words, the costs items, which are needed to move the product from producers to consumers, are ordinarily known as marketing cost. The per quintal marketing cost of groundnut of different actors like Faria for Tk.102, Bepari for Tk. 357, Arathdar for Tk. 55, Stockist for Tk.1388, Paiker for Tk.112 and Retailer for Tk.128 in all area. Transportation cost was the major cost item of all intermediaries which covers (25-38) \% of the total cost. Marketing cost of stockist was the highest among the intermediaries. Weight loss and damage was the highest cost item for stockist which covers $80 \%$ of the total marketing cost. Because they purchase wet groundnut from farmers and dry it in their chatal. The other cost items of the actors were loading, unloading, packaging, Arathdar commission, khajna etc. The cost varied from area to area depending on coverage of distance (Table13).

Table13. Marketing cost of different actors involved in the chain (Tk/qt)

\begin{tabular}{lcccccccc}
\hline Cost component & Faria & Bepari & Arathdar & Stockist & Paiker & Retailer \\
\hline Transportation & 26 & 152 & - & 29 & 32 & 19 \\
Loading & 7 & 20 & - & 10 & 14 & 12 \\
Unloading & 6 & 11 & - & 7 & 6 & 7 \\
Wages and salaries & - & - & 21 & - & - & - \\
Packaging & 13 & 20 & - & - & 14 & - \\
Commission & 18 & 52 & - & - & 18 & 62 \\
Accountant cost & - & - & 9 & - & - & - \\
Drying \& Grading & - & - & - & 52 & - & - \\
Khajna & 17 & 17 & - & - & 16 & - \\
Wastage and damage/Weight loss & - & 68 & - & 1111 & - & - \\
Shop rent & - & - & 6 & - & - & - \\
Chatal cost & - & - & - & 113 & - & - \\
Storage cost & - & - & - & 45 & - & - \\
Market toll & - & - & - & - & - & 12 \\
sweeper & - & - & 1 & - & - & - \\
Electricity cost & - & - & 5 & 4 & - & - \\
Telephone/Mobile & 6 & 9 & 5 & 6 & 6 & 7 \\
Entertainment & 9 & 8 & 8 & 11 & 7 & 9 \\
Total & 102 & 357 & 55 & 1388 & 112 & 128 \\
\hline
\end{tabular}

Marketing margin of different actors involved in the groundnut marketing

Marketing margin is the difference between the price paid by the consumer and price received by the producers. Marketing margin has two components 
marketing cost and net margin or profit. In broad sense, marketing margin is the difference between what is paid by the consumer and what is received by the producer. It is the price of all utility adding activities and functions that are performed by the intermediaries (Kohls and Uhl, 2005). It was revealed from the study that the net margin of the actors like Faria for Tk.232, Bepari for Tk.309, Arathdar for Tk.59, Stockist for Tk.1212, Paiker for Tk.254 and Retailer for Tk.305 per quintal. Among the intermediaries the stockiest added highest margin followed by Retailer, Bepari, Paiker, Faria and Arathdar (Table14). Because the stockist had done some marketing function such as drying the groundnut in their chatal and hold the quantity for higher price. On the other hand retailer has to sell small amount of groundnut for long period due to higher profit.

Table14. Marketing margin of different stages of marketing chain (Tk/qt)

\begin{tabular}{l|c|c|c|c|c|c}
\hline Particulars & Faria & Bepari & Aratdhar & stokiest & Paiker & Retailer \\
\hline $\begin{array}{l}\text { A. Average sales price } \\
\text { B. Average purchase }\end{array}$ & 4933 & 5933 & - & 4633 & 5733 & 6167 \\
price & 5267 & - & 2033 & 5367 & 5733 \\
C. Gross margin (A-B) & 334 & 666 & 114 & 2600 & 366 & 433 \\
D. Marketing cost & 102 & 357 & 55 & 1388 & 112 & 128 \\
E. Net Margin (C-D) & 232 & 309 & 59 & 1212 & 254 & 305 \\
\hline
\end{tabular}

\section{Marketing cost (MC) and Marketing margin (MM) distribution among the actors in the chain}

Table15 shows the marketing chain wise marketing cost (MC) and marketing margin (MM) of different actors of groundnut. The highest marketing cost and margin was observed in the marketing chain-ii followed by chain-iii, chain-i, chain-iv and chain-v. Because the stockist incurred highest marketing cost and margin in the chain-ii (Table15).

Table15. Marketing cost (MC) and marketing margin (MM) distribution among the actors

\begin{tabular}{|c|c|c|c|c|c|c|c|c|c|c|c|c|c|c|}
\hline \multirow{2}{*}{$\begin{array}{l}\text { Marketing } \\
\text { chain }\end{array}$} & \multicolumn{2}{|c|}{ Faria } & \multicolumn{2}{|c|}{ Bepari } & \multicolumn{2}{|c|}{ Arathdar } & \multicolumn{2}{|c|}{ Stockist } & \multicolumn{2}{|c|}{ Paiker } & \multicolumn{2}{|c|}{ Retailer } & \multicolumn{2}{|c|}{ Chain Total } \\
\hline & $\mathrm{MC}$ & MM & $\mathrm{MC}$ & MM & MC & MM & $\mathrm{MC}$ & MM & $\mathrm{MC}$ & MM & MC & MM & MC & MM \\
\hline Chain-i & 102 & 232 & - & - & 55 & 59 & - & - & 112 & 254 & 128 & 305 & 397 & 850 \\
\hline Chain-ii & 102 & 231 & 357 & 309 & - & - & 1388 & 1212 & - & - & 128 & 305 & 1975 & 2057 \\
\hline Chain-iii & - & - & 357 & 309 & 55 & 59 & - & - & 112 & 254 & 128 & 305 & 652 & 927 \\
\hline Chain-iv & - & - & - & - & - & - & - & - & 112 & 254 & 128 & 305 & 240 & 559 \\
\hline Chain-v & - & - & - & - & - & - & - & - & - & - & 128 & 305 & 128 & 305 \\
\hline
\end{tabular}




\section{Marketing efficiency}

Considering the above five chain on the basis of involvement of intermediaries it was found that marketing chain-v is the most efficient than other marketing chain followed by marketing chain-iv, chain-i, chain-iii and chain-ii. Marketing chain- $v$ has single involvement of intermediary for this farmer get higher share of the consumer price (Table16).

Table 16. Marketing efficiency of groundnut marketing (Tk/quintal)

\begin{tabular}{l|cccccc}
\hline Particulars & Chain-i & Chain-ii & Chain-iii & chain -iv & Chain-v \\
\hline 1. Price received by the Farmers (FP) & 4933 & 4933 & 5267 & 5367 & 5733 \\
2.Total marketing cost (MC) & 397 & 1975 & 652 & 240 & 128 \\
3.Total net marketing margin (MM) & 850 & 2057 & 927 & 559 & 305 \\
$\begin{array}{l}\text { 4. Marketing efficiency \{FP/ } \\
\text { (MC+MM)\} }\end{array}$ & 3.95 & 1.22 & 3.34 & 6.72 & 13.24 \\
\hline
\end{tabular}

\section{Marketing problems identified by the traders}

The intermediaries were faces different marketing problems during their business. Eighty two percent farmers were suffered lack of cash capital during their business. Seventy five percent farmers had to paid high charge for transportation followed by high interest rate (65\%), unstable price $(58 \%)$ and lack of storage facilities (55\%) (Table17.).

Table 17. Marketing problems identified by the traders

\begin{tabular}{l|c|c|c|c}
\hline \multirow{2}{*}{\multicolumn{1}{c}{ Particulars }} & \multicolumn{4}{c}{ Percent of traders } \\
\cline { 2 - 5 } & Faridpur & Jamalpur & Kishoreganj & All area \\
\hline Lack of cash capital & 82 & 80 & 84 & 82 \\
High transportation cost & 72 & 78 & 75 & 75 \\
High rate of interest & 65 & 62 & 68 & 65 \\
Unstable price & 61 & 55 & 58 & 58 \\
Lack of storage facilities & 61 & 54 & 50 & 55 \\
\hline
\end{tabular}

\section{Probable solutions identified by the traders}

The traders were mentioned some options to remove the above constraint of groundnut marketing in the study areas. These were arrangement of institutional credit with low interest rate $(80 \%)$, government incentives to reduce transportation cost (67\%), collateral free credit (45\%) and arrangement of storage facilities $(73 \%)$ etc. (Table-18). 
Table 18. Probable solutions suggested by the traders

\begin{tabular}{l|c|c|c|c}
\hline \multirow{2}{*}{ Probable solutions } & \multicolumn{4}{c}{ Percent of traders } \\
\cline { 2 - 5 } & Faridpur & Jamalpur & Kishoreganj & All area \\
\hline Credit with low interest rate & 86 & 80 & 74 & 80 \\
$\begin{array}{l}\text { Government incentives to reduce } \\
\text { transportation cost }\end{array}$ & 65 & 69 & 68 & 67 \\
Collateral free credit & 52 & 43 & 40 & 45 \\
Arrangement storage facilities & 72 & 76 & 71 & 73 \\
\hline
\end{tabular}

\section{Conclusion and Recommendations}

The study discussed the details of groundnut production and marketing in char lands of the study areas. Char lands are not suitable for maximum crop production and most of the char lands were remain fellow half of the year or used for single crop. Groundnut was profitable crop in char lands because it requires fewer amounts of fertilizer, pesticides and irrigation compared to other crops. The study revealed that per hectare groundnut production was profitable than its competitive crops wheat and sesame. It has also some opportunities for groundnut production in char lands such as sandy soil, less water and fertilizer requirement, high yield compared to input uses, low labour requirement etc are favorable to farmers for groundnut cultivation. Most of the farmers used local or traditional variety for groundnut cultivation in char lands. Maximum production of groundnut was consumed and marketed locally and rest of the production was kept by farmers as a seed. The study also identified five mojor marketing chain of groundnut marketing. The actors of the groundnut marketing chain were Faria, Bepari, Arathdar, Stockiest, Paiker and Retailer. A good amount of marketing margin was received by the actors at different stages of marketing chain. The study also showed the marketing margin distribution among the actors of the marketing chain as well as efficiency of the marketing chain. The longer the marketing chain the lower the producer share as well as marketing efficiency. The study also identified some production and marketing problems of groundnut cultivation and also suggested some policy options which are recommendation of the study.

So the recommendations of the study were farmers used less inputs to groundnut production in char lands so there is a opportunities to increase groundnut production by using adequate inputs like irrigation, fertilizer, pesticides etc. Farmers also need HYV seed for groundnut production because survey report revealed that $67 \%$ farmer used Dhaka-1 and local variety for groundnut production. Interest free agricultural credit, irrigation facilities and government incentives to seed, fertilizer and pesticides in proper time will be helpful to remove the problems of groundnut cultivation. Modern storage facilities should 
be developed for short time storage of groundnut at important assemble center. Efficient marketing system should be developed by eliminating unnecessary middlemen in the marketing chain. Transportation facilities should be improved in the char areas so that the rickshaw, van, truck and other vehicles could move easily. Boat, cargo should be initiated in the river way as possible; it would helpful to reduce transportation cost largely.

\section{References}

Acharya, S. S. and N. L. Agarwal. 2004. Agricultural Prices Analysis and Policy, Oxford and IBH Publishing Co. PVT. LTD, Calcutta

BBS. 2011. Year Book of Agricultural statistics of Bangladesh, Ministry of Planning, Government of the People's Republic of Bangladesh, Dhaka.

BSS. 2012. Char people changing fates thru' groundnut cultivation, Bangladesh Sangbad Sanstha, National News Agency of Bangladesh, BSS IT Division, Dhaka.

BSS. 2013. Groundnut changes economic life of char people, The Financial Express, Bangladesh Sangbad Sanstha, and Dhaka.

Ferris R.S.B., C. Collinson, K.Wanda, J. Jagwe and P. Wright. 2001. Evaluating the marketing opportunities for shea nut and shea nut processed products in Uganda. A report prepared for USAID. P.77.

Kohls, R. L. and J. N. Uhl. 2005. Marketing of agricultural products. $9^{\text {th }}$ edition. Macmillan Publishing co.,Inc., New York.

Rahman, S and J. Davis. 2005. A survey of rural livelihood and enterprise development opportunities in the Chars, Bangladesh, DFID Poverty Oriented Research Programme, Natural Resource Institute, University of Greenwich. 